\title{
Demand management based design of residential solar power supply system: a techno-economic evaluation
}

\author{
*V.O. Oladokun and S.A. Adeshiyan \\ Department of Industrial and Production Engineering University of Ibadan, Ibadan, Nigeria \\ *vo.oladokun@mail.ui.edu.ng; +2348033919050
}

\begin{abstract}
With high solar radiation across Nigeria, solar power system can become a viable solution to the Nigeria's electricity power crisis if the problem of high capital cost of solar power supply system can be addressed. In this study the use of demand management based design approach has been explored for reducing the capital cost of residential solar power supply system. Utilities and energy demands of thirty randomly picked homes in selected residential areas were studied. The houses were classified into one, two and three rooms' residential apartments. New energy efficient appliances that can deliver the same or higher utility values as those already in use in these houses were identified and proposed as replacement to cut energy demand. Cost analysis of replacement with these energy star appliances was carried out. Solar system designs and associated cost models were developed for both the existing demand system and the proposed energy efficient demand system. For comparative analysis, appliances replacement cost was factored into the associated solar system capital cost. The average total energy demands were $1255 \mathrm{~W}, 1785 \mathrm{~W}$, and 2185 for one, two, and three bedroom flats respectively while equivalent demands for energy efficient system are $389 \mathrm{~W}, 820 \mathrm{~W}$, and $851 \mathrm{~W}$ respectively. The cost of designing and installing a solar power with the replaced appliances exhibits a significant reduction of $64.88 \%, 64.5 \%$ and $62.16 \%$ for the one, two and three rooms residential set up respectively. We conclude that an integrated demand management design approach is very useful in reducing the capital cost of residential solar systems.
\end{abstract}

Keywords: Solar, Power, Demand management, Cost model, Residential

\section{INTRODUCTION}

Meeting the power need of Nigeria has remained a serious challenge to government and the crisis in the power sector has literally grounded the nation's economy. The use of solar power supply system has been identified as a possible renewable energy source for Nigeria and other developing countries (Mpagalile et al, 2006\&2007; Arne, 2007). In addition solar power system is environmentally friendly, safe, and has no gas emissions nor generates noise (Al-Salaymeh et al, 2009) with strong support for its use from world bank, UN and other international agencies Karekezi and Kithyoma, 2002; Villavicencio, 2002). Though the operation cost of solar system is low and attractive to consumers the high initial set up cost per Kwhr of solar powered system has limited or discouraged its use in realistic residential applications. Generally the utilization of solar panels for domestic applications differs dramatically from county to country, with Germany having reached a level of $50 \%$ of domestic homes with solar thermal, against the UK with around $2 \%$; figure for Nigeria, though not available, is obviously negligible due to its relatively high acquisition cost. The economics of solar are moderated by a balance between the high initial cost of a solar PV system and very low subsequent running costs compared to the low initial cost of, say, a diesel generator with very high operation and maintenance costs. Generally installation cost is directly proportional to system power rating. The cost of installing a typical offgrid PV system in a home ranges from $\$ 15,000$ to $\$ 20,000$ per kilowatt.

However the KWhr/day consumption of typical residential home is a function of the efficiencies of appliances and gadgets in use such that if proper consideration is given to appliances efficiencies at design stage the same or high level of utility can be derived from less Kwhr requirement. This demand management or Input-Output based design approach is the focus of this study. 
Presently there are three basic steps in the design of a PV system: 1) Estimation of Load and Load profile, 2) Estimation of available solar radiation, and 3) The design of Solar System based on 1and
2 as illustrated in figure1. While conceptually, we are proposing an approach illustrated in figure2 for the design residential solar power supply system.

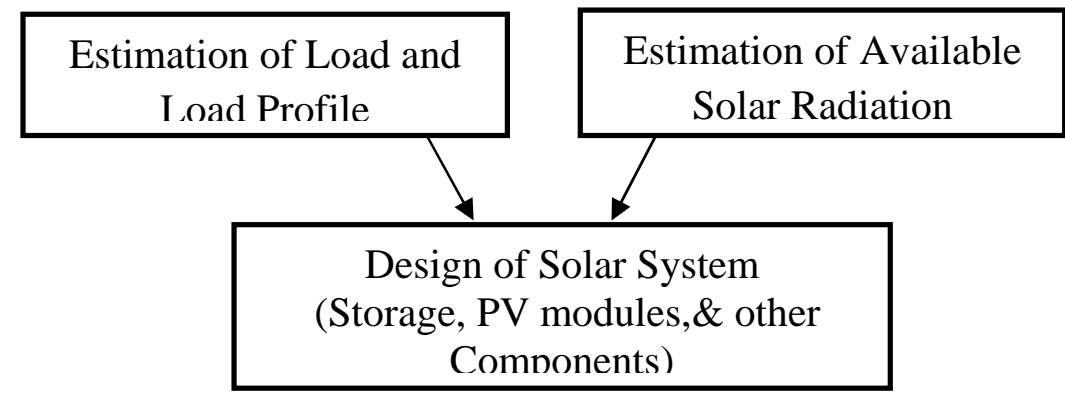

Fig1 Output-based solar system design

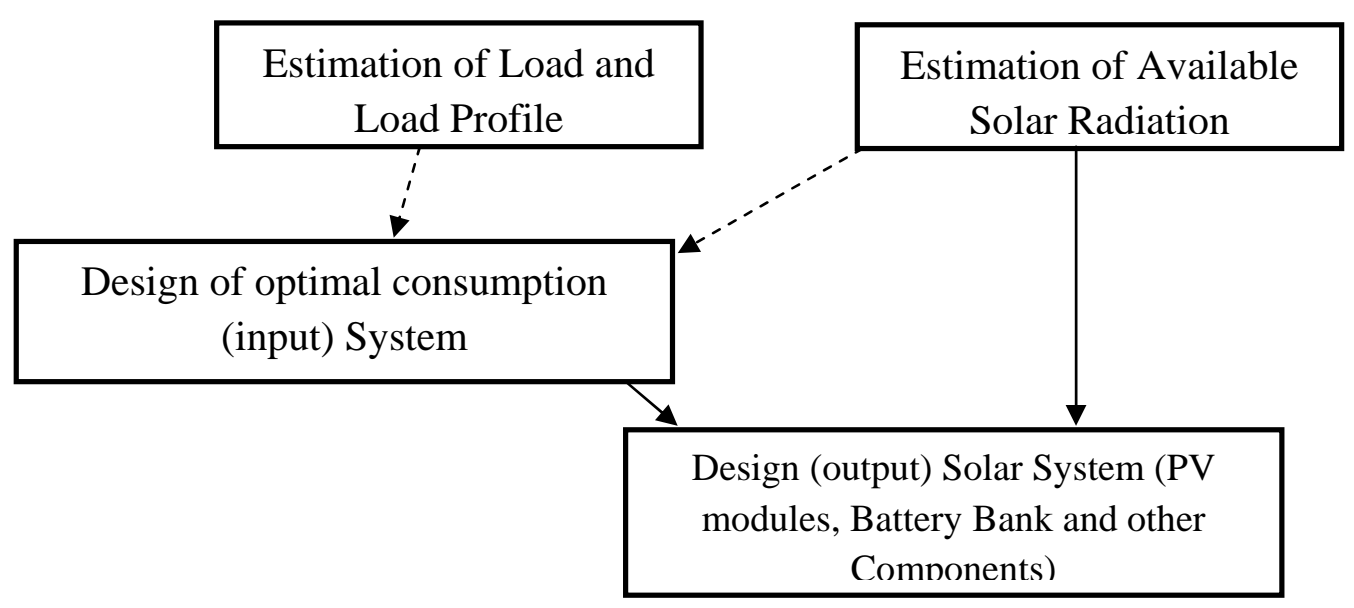

Fig 2 Input-Output (Demand Management) based solar power system design

The aim of this project is to provide a technical and economic assessment of a load input based residential solar system. The principal objectives are 1) determine the basic appliances in a residential set up, and the power consumption of these appliances, 2) identify alternative energy efficient home appliances as the basis for solar electricity system design, 3) carry out designs based on this energy efficient system of appliances.

Solar Power supply System: an Overview: Solar energy is utilized in buildings in two ways one, using solar systems to supply heat to warm up spaces through solar collector, and two using solar systems to generate electricity through Photovoltaic (PV) cells). Photovoltaic cell (PV) device is a direct conversion system which converts light into electric current requiring no intervening heat engines using the photoelectric effect. The output of PV devices can range from micro watts to mega watts. Also because solar radiation is intermittent there is always a need for storage systems so that it could make available whenever it is needed. The storage system adopted is in fact critical to system performance and reliability (Teoman, 1992; Goswami et al, 2000).

The use of solar energy system cut across many areas applications such as desalination, crop drying, lighting, and powering of small household appliances and its of areas applications will continue to expand as cost drops (Eswaramoorthy and Shanmugam, 2006). There are many new technologies, such as 
fiber optic photovoltaic and other types of photovoltaic cells, such as thin film, monocrystalline silicon, polycrystalline silicon, and amorphous cells, as well as multiple types of concentrating solar power that are being explored for the possibilities of producing cheaper solar modules, However these technologies are still many years away from mass production (Bingham, 2003).

\section{METHODOLOGY}

\section{The Residential Solar System Cost Model}

Where $\mathrm{C}_{S}=$ Cost of solar panel $\left(C_{S 1}\right)+$ Cost of inverter $\left(C_{S 2}\right)+$ Cost of batteries $\left(C_{S 3}\right)+$ Cost of charge controller $\left(C_{S_{4}}\right)+$ Cost of installation

$\left(C_{S 5}\right)$

$C_{a}=$ Energy efficient appliances replacement

Cost

\section{Model development}

If $\mathrm{P}=$ total load $=\sum_{j=1}^{m} p_{j}$

Such that $P$ is $P_{a}=$ total load if solar system is designed for conventional appliances and

$P$ is $P_{e}=$ total load if system is designed for energy star appliances.

$\mathrm{k}=$ capital cost per unit Watt of solar power system. Then $C_{S}$, Capital cost of solar system is given by

$$
\begin{aligned}
& C_{S}=k P=k \sum_{j=1}^{m} p_{j} \\
& T_{C}=k P+C a
\end{aligned}
$$

When the supply system is designed for conventional appliances with no need for appliances replacement then

$T_{C}=T_{C 1}=k P_{a}$

However when power system is designed for energy efficiency requiring the replacement of existing appliances with energy star ones then
Notation:

$\mathrm{i}=$ the index identifying solar system components

$\mathrm{m}=$ no of appliances in home to put on solar

$\mathrm{j}=$ index identifying household appliances $\mathrm{j}=1 \ldots . \mathrm{m}$

$T_{C}=$ The total cost of a solar power system

$C_{S}=$ Capital cost of solar system

$r_{i}=$ the replaceable appliances in the residential set up

$\mathrm{p}_{\mathrm{j}}=$ Power rating appliance $\mathrm{j}$

$\mathrm{Sv}=$ salvage value of replaced appliances

$T_{C}=T_{C 2}=k P_{e}+C a$

So that Cost savings $\Delta \mathrm{T}_{\mathrm{C}}$ is given by

$\Delta \mathrm{T}_{\mathrm{C}}=\mathrm{T}_{C 1}-\mathrm{T}_{C 2}=k\left(P_{a}-P_{e}\right)-C_{a}$

Eqn 4 can be written in terms individual appliances load as follows.

$\Delta \mathrm{T}_{\mathrm{C}}=k\left(\sum_{j=1}^{m}\left(p_{a j}-p_{e j}\right)-C_{a}\right.$

And \% savings is given by

$\left(\Delta \mathrm{T}_{\mathrm{C}} / \mathrm{T}_{\mathrm{C} 1)} \times 100=\left(1-P_{e} / P_{a}-C_{a} / k P_{a}\right) \times 100\right.$

Where a positive \% savings indicates that expenses on appliances replacement is justifiable in the solar system design.

If the replaced appliances are resalable at some salvage value Sv then 5 holds giving additional savings

$\Delta \mathrm{T}_{\mathrm{C}}$

$=T_{C 1}-T_{C 2}=k\left(P_{a}-P_{e}\right)-C_{a}+S_{v} \cdots \cdots$

\section{Energy Audit:}

Energy audit of selected residential apartments was carried out using structured questionnaires and interviews. Random sampling technique was adopted to select 30 apartments covering three 
main types of residential set ups; one room, two rooms, and three rooms residential set up. The study was carried out on the staff quarter of a University community based in South West Nigeria to identify the appliances used for home utilities. Market survey of appliances was carried out in three major markets in Lagos Nigeria to identify available alternative energy efficient or energy star rated appliances that can provide the required utilities. The average total energy demands were $1255 \mathrm{~W}, 1785 \mathrm{~W}$, and 2185 for one, two, and three bedroom flats respectively while equivalent demands for energy efficient system are $389 \mathrm{~W}, 820 \mathrm{~W}$, and $851 \mathrm{~W}$ respectively as shown in table 1

Table1 Comparison of Energy Demand: Existing Vs Energy efficient Appliances

\begin{tabular}{|c|c|c|c|c|c|c|c|c|c|c|c|c|}
\hline \multirow[t]{4}{*}{ Utility } & \multirow{4}{*}{$\begin{array}{l}\text { Appliances in } \\
\text { Use }\end{array}$} & \multirow{4}{*}{$\begin{array}{l}\text { Energy } \\
\text { efficient } \\
\text { Appliances }\end{array}$} & \multirow{4}{*}{$\begin{array}{c}\text { Ave } \\
\text { daily } \\
\text { run } \\
\text { time } \\
\text { Hrs }\end{array}$} & \multicolumn{9}{|c|}{ Apartment types } \\
\hline & & & & \multicolumn{3}{|c|}{ One room } & \multicolumn{3}{|c|}{ Two rooms } & \multicolumn{3}{|c|}{ Three rooms } \\
\hline & & & & \multirow[t]{2}{*}{ No } & $\mathrm{P}_{\mathrm{aj}}$ & $\mathrm{P}_{\mathrm{ej}}$ & \multirow[t]{2}{*}{ No } & $\mathrm{P}_{\mathrm{aj}}$ & $\mathrm{P}_{\mathrm{ej}}$ & \multirow[t]{2}{*}{ No } & $\mathrm{P}_{\mathrm{aj}}$ & $\mathrm{P}_{\mathrm{ej}}$ \\
\hline & & & & & \multicolumn{2}{|c|}{ Watts } & & \multicolumn{2}{|c|}{ Watts } & & \multicolumn{2}{|c|}{ Watts } \\
\hline \multirow[t]{2}{*}{$\begin{array}{l}\text { Home } \\
\text { theatre }\end{array}$} & $\begin{array}{l}14 \text { inches T.V } \\
\text { (75) }\end{array}$ & $\begin{array}{l}14 \text { inches } \\
\text { T.V }(60)\end{array}$ & 4 & 1 & 75 & 60 & 2 & 150 & 120 & 2 & 150 & 120 \\
\hline & Radio (210) & Radio (50) & 3 & 1 & 210 & 50 & - & - & - & - & - & \\
\hline \multirow[t]{2}{*}{ Computer } & Laptop (85) & Laptop (64) & 2 & 1 & 250 & - & 1 & 85 & 64 & 1 & 85 & 64 \\
\hline & Desktop (250) & Laptop (64) & 2 & & & 64 & - & - & - & & & \\
\hline Fan & Fan (100) & Fan (45) & 2 & 2 & 200 & 90 & 3 & 300 & 135 & 3 & 300 & 135 \\
\hline D.V.D & D.V.D (100) & D.V.D (20) & 2.5 & 1 & 100 & 20 & 1 & 100 & 20 & 1 & 100 & 20 \\
\hline Blending & $\begin{array}{l}150 \mathrm{ML} \\
\text { Blender (300) }\end{array}$ & $\begin{array}{l}150 \mathrm{ML} \\
\text { Blender 200) }\end{array}$ & 6 & - & - & - & 1 & 300 & 200 & 1 & 300 & 200 \\
\hline \multirow[t]{2}{*}{$\begin{array}{l}\text { Refriger- } \\
\text { ation }\end{array}$} & $\begin{array}{l}250 \text { L Freezer } \\
(90)\end{array}$ & $\begin{array}{l}250 \mathrm{~L} \\
\text { Freezer (87) }\end{array}$ & 8 & - & - & - & - & - & - & 1 & 90 & 87 \\
\hline & $\begin{array}{l}250 \mathrm{~L} \text { fridge } \\
(150)\end{array}$ & $\begin{array}{l}250 \mathrm{~L} \\
\text { Freezer (87) }\end{array}$ & 8 & - & - & - & 1 & 150 & 87 & - & - & - \\
\hline \multirow[t]{3}{*}{ Lightning } & $\begin{array}{l}\text { Type A Bulbs } \\
(100)\end{array}$ & $\begin{array}{l}\text { Energy star } \\
\text { bulb (15) }\end{array}$ & 6 & 7 & 420 & 105 & - & - & - & 8 & 800 & 120 \\
\hline & $\begin{array}{l}\text { Type B Bulbs } \\
(60)\end{array}$ & $\begin{array}{l}\text { Energy star } \\
\text { bulb (15) }\end{array}$ & 6 & - & - & - & 9 & 540 & 135 & 4 & 240 & 60 \\
\hline & $\begin{array}{l}\text { Florescent } \\
\text { lamps (40) }\end{array}$ & $\begin{array}{l}\text { Energy star } \\
\text { bulb (15) }\end{array}$ & 8 & - & - & - & 4 & 160 & 60 & 3 & 120 & 45 \\
\hline \multicolumn{4}{|c|}{ Total Loads } & \multicolumn{2}{|c|}{$\begin{array}{l}P_{a}= \\
1255 W\end{array}$} & $\begin{array}{l}P_{e}= \\
389 W\end{array}$ & \multicolumn{2}{|c|}{$\begin{array}{l}P_{a}= \\
1785 W\end{array}$} & $\begin{array}{l}P_{e}= \\
820 W\end{array}$ & \multicolumn{2}{|c|}{$\begin{array}{l}P_{a}= \\
2185 W\end{array}$} & $\begin{array}{l}P_{e}= \\
851 W\end{array}$ \\
\hline
\end{tabular}

${ }^{*}$ Note Heating/Ironing activities will not be put on the solar system. The residents can schedule heating, ironing on the Public power system.

Systems Design and Cost savings: Based on the result of the audit and survey studies engineering designs of the solar power supply systems were carried out for the three types of flats. The Watt-hour for each utility was estimated and summed to obtain the system Watt hour for each of the apartment type. For the purpose of comparison the designs for both convectional and energy efficient systems were carried out for each of the apartment type.

These designs were used to generate the cost implications of solar systems based on existing appliances and energy efficient appliances. Figure 3 is a typical model for the single apartment design while detailed design is available in 
Am. J. Sci. Ind. Res., 2012, 3(1): 21-26

Adeshiyan (2010). This empirical equivalence of cost model represented by equations $2,3,4$, and
5 is as shown in table 2 for each of the three types of apartment.

Table 2 Costing: Existing vs Energy star based system

\begin{tabular}{|c|c|c|c|c|}
\hline \multirow[t]{2}{*}{ Solar system component } & \multicolumn{2}{|c|}{ Existing Utility } & \multicolumn{2}{|c|}{$\begin{array}{l}\text { Energy efficient } \\
\text { Utility }\end{array}$} \\
\hline & Units & Cost $\mathrm{N}$ & Units & Cost N \\
\hline \multicolumn{5}{|c|}{ Single bedroom apartment } \\
\hline Solar Panel & 10 & 800,000 & 2 & 160,000 \\
\hline Batteries & 36 & $1,800,000$ & 12 & 600,000 \\
\hline Inverter & 1 & 80,000 & 1 & 50,000 \\
\hline Sub -total & & $2,680,000$ & & 810,000 \\
\hline Appliances replacement & & 0 & & 131,150 \\
\hline Total & & $2,680,000$ & & 841,150 \\
\hline \multicolumn{5}{|c|}{ Two bedroom apartment } \\
\hline Solar Panel & 20 & 1600000 & 3 & 240000 \\
\hline Batteries & 60 & $3,000,000$ & 24 & $1,200,000$ \\
\hline Inverter & 1 & 100,000 & 1 & 50,000 \\
\hline Sub -total & & $4,700,000$ & & $1,490,000$ \\
\hline Appliances replacement & & 0 & & 177,850 \\
\hline Total & & $4,700,000$ & & $1,667,850$ \\
\hline \multicolumn{5}{|c|}{ Three bedroom apartment } \\
\hline Solar Panel & 22 & $1,760,000$ & 4 & 320,000 \\
\hline Batteries & 60 & $3,000,000$ & 24 & $1,200,000$ \\
\hline Inverter & 1 & 120,000 & 1 & 50,000 \\
\hline Sub -total & & 4880000 & & $1,570,000$ \\
\hline Appliances replacement & & 0 & & 276,250 \\
\hline Total & & $4,880,000$ & & 1,846250 \\
\hline
\end{tabular}

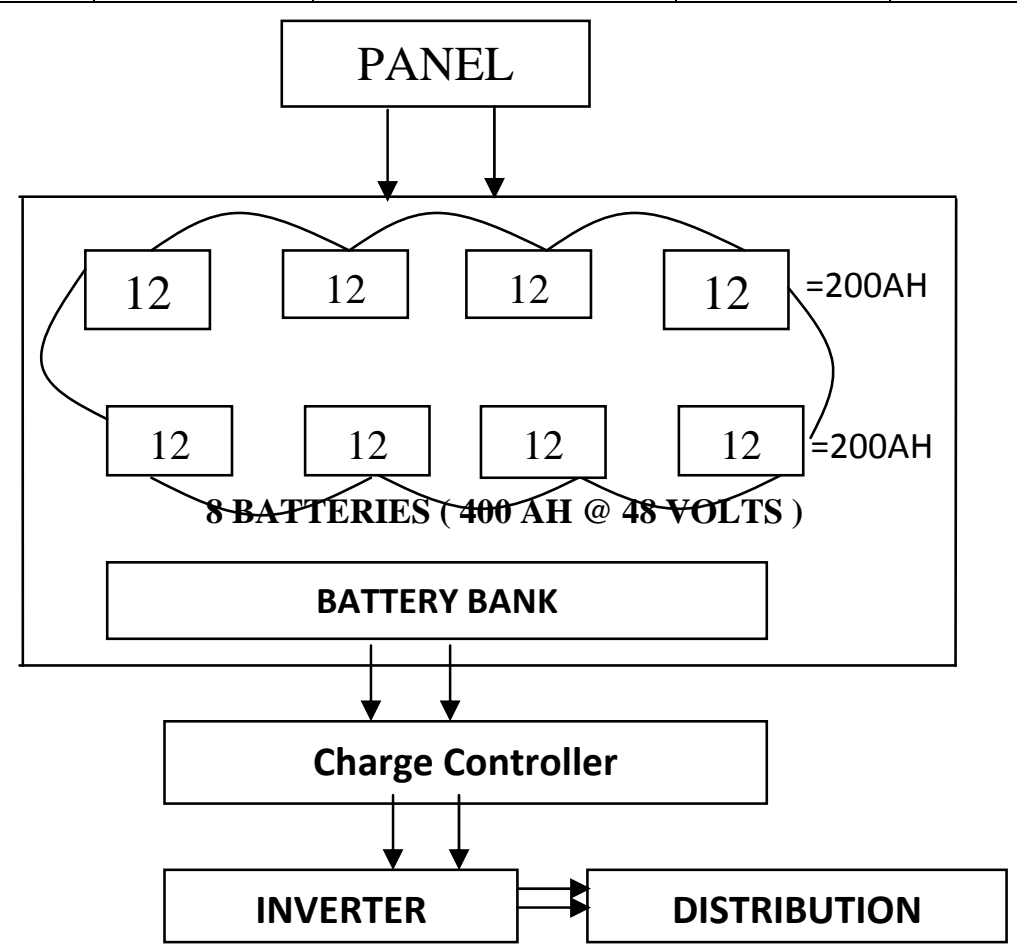

Fig 3: Model diagram of P.V Subsystems for a typical one room residential set up. 


\section{CONCLUSIONS}

The cost of designing and installing a solar power with the replaced appliances translates into a significant reduction of $64.88 \%, 64.5 \%$ and $62.16 \%$ for the one, two and three rooms residential set up respectively. This is because appliances replacement costs for the residential apartments were relatively low compared to the total amount saved on solar installation costs. This integrated input-output system design approach thus provides a very good alternative to reducing the capital cost of residential solar electricity systems.

\section{REFERENCES}

Adeshiyan S.A. (2010). An output-input design based techno-economic evaluation of residential solar power supply system. An MSc Project report at the Department of Industrial and Production Engineering University of Ibadan, Ibadan, Nigeria.

Al-Salaymeh A, Al-Hamamre Z and Firas S (2009). Technical \& Economical Assessment of the Utilization of Photovoltaic Systems in Residential Buildings: The case of Jordan. Faculty of Engineering and Technology, University of Jordan, Amman 11942, Jordan. GCREEDER

Arne J (2007). Connective Power: Solar Electrification and Social Change in Kenya. World Development Vol. 35, No. 1, pp. 144-162

Eswaramoorthy M and Shanmugam C (2006). TechnoEconomic Analysis of a Standalone Solar
Thermoelectric Power Generator for Rural Residential Energy Demand. International Journal of Applied Engineering Research Volume 4 No 10 pp. 19111919

Karekezi, S., and Kithyoma, W ( 2002) Renewable energy strategies for rural Africa: is a PV-led renewable energy strategy the right approach for providing modern energy to the rural poor of sub-Saharan Africa. Energy Policy, Vol 30, 1071-1086.

Mpagalile J.J, Hanna M.A, and Weber R. (2006). Design and testing of a solar photovoltaic operated multiseeds oil press. Renewable Energy, Vol 31, 18551866.

Mpagalile J.J, Hanna M.A, and Weber R, (2007). Seed oil extraction using a solar powered screw press. Industrial Crops and Products, Vol 25 No 1, 101-107.

Teoman A, Kamil K, and Omer C (1992). Solar assisted heat Pump and Energy for Domestic Heating in Turkey. Proceedings of the second World Renewable Energy Congress Reading, U.K. World Renewable Company. p 687-691

Villavicencio A (2002). Sustainable energy development: the case of photovoltaic home systems. Report for UNEP Collaborating Centre on Energy and Environment, Riso National Laboratory, Roskilde, Denmark.

Goswami Y.G, Kreith D.F, and Kreider J.F (2000). Principle of solar Engineering, second edition, Tailor and Francis 